\title{
IDENTIFYING AS A DRAG QUEEN AND THE MEANING OF WORK
}

\author{
THAÍS Z. G. DE OLIVEIRA ${ }^{1}$ \\ (iD) https://orcid.org/0000-0003-1130-0810 \\ LUDMILA DE V. M. GUIMARÃES \\ (iD) https://orcid.org/0000-0001-5741-0279 \\ MARIANA DE L. CAEIRO 3 \\ (iD) https://orcid.org/0000-0003-2257-6767 \\ ADMARDO B. GOMES JÚNIOR \\ (iD) https://orcid.org/0000-0002-2349-0335
}

To cite this paper: Oliveira, T. Z. G., Guimarães, L. V. M., Caiero, M. L., \& Gomes Júnior, A. B. (2018). Identifying as a drag queen and the meaning of work. Revista de Administração Mackenzie, 19(spe). doi:10.1590/1678-6971/eRAMD180060

Submission: Apr. 24, 2018. Acceptance: Aug. 8, 2018.

1 Universidade Federal de Minas Gerais (UFMG), Belo Horizonte, MG, Brazil.

2 Centro Federal de Educação Tecnológica de Minas Gerais (CEFET-MG), Belo Horizonte, MG, Brazil. 3 Pontifícia Universidade Católica de Minas Gerais (PUC-MG), Belo Horizonte, MG, Brazil.

\section{(cc) BY}




\section{ABSTRACT}

Purpose: This study examines the identification processes that marked the life of a subject and their possible relations with the meaning of work as a drag queen.

Originality/value: This study stands out in its use of a theoretical psychoanalytic framework to analyze the life history of a professional drag queen, aiming to shed light on the senses of work from singular aspects of the worker. Research on this subject in the field of administration is usually conducted within a functionalist paradigm.

Design/methodology/approach: We examined the life story of a drag queen from Belo Horizonte, Minas Gerais. The choice to use "life story" as a data collection and analysis strategy allowed us to illuminate how the subject lives and articulates his story and the choice of work that allows an expression of his desire.

Findings: Some points combine the subject's identity traits with his work as a drag artist; the look and clothes are elements that sustain a fantasy that has found a place in society. One of the elements that gives meaning to the work is the link of some singular identity traits with the social dimension of work and the affections that sustain a form of social recognition.

\section{KEYWORDS}

Drag queen. Work. Life story. Gaze. 


\section{INTRODUCTION}

Studies on the meaning of work, whether in the field of administration or psychology, are marked by a perspective that considers work that offers workers the maximum positive meaning and motivates them to accomplish tasks. Meaningful work will facilitate subjective engagement of the worker in its fulfillment. This generalization seems indisputable to us. However, an attentive look at the singularities and peculiarities that the work place occupies in the affections of individuals causes us to ask new questions. From a psychoanalytic perspective, how do the relations between identity and work take place? How does one include a dimension of meaning that carries a value (positive or negative)?

This article begins with the life story of a subject who works as a drag artist, aiming to understand the elements of the identity construction that marked subject's life history and the possible relations with the meaning of the work the subject performs.

We are aware that we have not exhausted, nor did we intend to exhaust, the myriad elements that make up the phenomenon of the many drag queen and drag artist practices from either a subjective point of view or in the issues raised as a professional practice. The contributions already made by psychoanalysts in the field of contemporary practices of transitions between masculine and feminine were not the focus of our attention here.

The justification for bringing concepts and reading possibilities from psychoanalysis to the administration and study of organization, work, and its management forms is based on the fact that we can broaden the understanding of the phenomena at stake when we refer to the phrase "meaning of work." Not everything that makes up the meaning of work is conscious. The meaning of work also contains a dimension of the unconscious desire that relates to each of us, which, in its complexity, can be accessed only individually through methods close to what we recognize as more clinical methods of work analysis (Gomes Júnior, Lopes, \& Guimarães, 2015). Further, psychoanalysis is able to contribute to a view on contemporary organizations, offering a critical and explanatory perspective for this context (Arnaud, 2012; Fotaki, Long, \& Schwartz, 2012; Arnaud \& Vanheule, 2007).

Therefore, we start from the life story of a worker using some contributions from psychoanalysis to read the narrative presented by the research subject. The choice to use the "life history" methodology allowed us to illuminate how the subject lives and articulates history and the choice 
of work that enables the subject to express personal desire. From the analysis, it was possible to highlight points that link some identity traits to the work as a drag artist; the look and clothes are elements that sustain a fantasy that has found a place in society. Thus, with this particular case, we believe we have demonstrated that one of the elements that gives meaning to work is the link to something that is always unique to each subject and that finds, in the social dimension of work, the affections that sustain a form of recognition.

\section{ART AND WORK IN DRAG QUEEN CULTURE}

Drag queen performativity could be presented from different angles. That is, it does not have only one origin and is not derived from only one type of theatrical modality. Drag performance has a strong connection with classical manifestations of the ancient scenic world, oriental folklore, medieval Christian staging, and, later, pop culture entertainment. In the Middle Ages, for example, the Catholic Church used theatrical plays as a strategy for evangelization, and, because of the small participation of women, young boys were trained to interpret asexual angels or Marys (Amanajás, 2015). These can be considered as the initial moments of what today is close to our understanding of the performative activity of drag queens.

The history of humanity presents innumerable passages in which the act of dressing (setting up) in drag, besides being an artistic and political positioning, was a scenic need imposed by the society and the morality of the time. From classical Greece to the present day, men personify the feminine image in different aspects, from the most realistic way to the total stylization of the form. The drag queen went through real metamorphoses both in its aesthetics and in its function but never lost its main objective-the great art of strangeness. (Amanajás, 2015, p. 1)

Considering a succinct contextualization of this phenomenon, it is important to locate it and present elements, although briefly, of the context of the performative activity of drag queens. According to Jayme (2001), cross-dressers can be considered part of the social group denominated as transgender. This group unfolds in different modes of experiences, considered massively as feminine or masculine. Among these modes are transvestites, drag artists, drag queens, and transsexuals. 
It is important to emphasize that these categories are neither stationary nor completely disassociated; they have intersections that manifest in the unique experience of each subject such that they transpose between domains that, from a heteronormative perspective (Butler, 1990), would be isolated as masculine or feminine. Further, Jayme (2001) points out that the understanding of these groups in terms of closed categories is unrealistic since such categorization processes necessarily use resources from popular language.

For this author, this must be problematized since such linguistic parameters are supported in a flowing social context that moves according to time (history) and the cultural scenario of each place. For example, it is currently common in Brazil to use the word montada (set up) for men who dress as women sporadically without the obligation to perform as drag queens and without the intention to identify themselves as transvestite, drag artist, or transsexual (Jayme, 2001).

Postmodern trends also reveal other terms commonly used to designate practices related to this gender ambiguity-that is, other ways of being transgender, such as being a cross-dresser (drag artist), androgyne, intersex, and queer. In this case, considering that drag queens form one of the possible subsets of transvestism, it is important to have a definition that is capable of defining this practice in its complexity. According to Alvarez and Perez (2009), drag artists are "a group marked by an uncertainty regarding gender identity with which they are identified since, being men, they usually use women's clothing and accessories to resemble a woman during a performance" (Alvarez \& Perez, 2009, p. 29).

Additionally, in the face of all this ambiguity, it is essential to take these definitions from those who identify themselves in this way. Therefore, according to this author, it would be common for drag performance to be linked to an artistic manifestation. Adopting the speech of several drag artists from Chile, Alvarez and Perez (2009) identify this artistic characteristic, given that the presentations are usually inserted in a dynamic in which its manifestation generates a series of affections and sensations from both the audience and the artists.

Recently, drag culture left the underground and entered the mainstream of advertising and international standards of consumption. This cultural pattern is represented, among other factors, by exuberant dresses, heavy makeup, and expansive behaviors (Silva, 2015). With the spread of drag culture internationally and the LGBTT (Lesbian, Gay, Bisexual, Transvestite, and Transsexual) movements at the end of the 20th century, drag culture, 
which until then had been marginalized, joined the movement for sexual and gender liberation (Amanajás, 2015).

In today's context, the US TV series RuPaul's Drag Race has been popularizing and stylizing drag culture on television since 2009. In this reality show, each new season sets a new record for audience size and gains more sponsors, exporting aesthetic consumption patterns to an increasingly broad public and lifting from marginalization artists whose work involves this type of performance. This has proven to be a business niche in the marketing arena in Brazil, where large companies link their advertising campaigns to renowned drag queens (Moraes, 2015).

Normally, drag queens are not essentially considered transgender; for some authors, this practice can even be understood as a category of theatrical work (Baker, 1994; Jesus, 2012; Chidiac \& Oltramari, 2004). On the other hand, Caproni Neto (2016) argues that disassociating drag queens from the context of gender dynamism may only partially embrace the reality of the situation. This divergence happens because drag queens, although manifesting an exaggerated femininity in their performances, often maintain some elements of the masculine gender in their daily lives (Chidiac \& Oltramari, 2004). Linking this practice only to the professional context suppresses these important nuances due to a mistaken need for objective categorization.

According to Pelúcio (2009), drag queens in Brazil, despite gaining notoriety since the 1990s, have been present even on the political scene since the 1970s in manifestations against the consequences of the military dictatorship in terms of censorship and restrictions on freedom of speech. In addition, even before this period, in the times of colonial Brazil, the drag was present through Portuguese scenic influences with magazines, vaudevilles, and melodrama (Pelúcio, 2009). The difference is that drags in present times, after following a long trajectory of changes and adaptations, have gained a more comical format and are inspired by the so-called "pop divas" with a strong American influence.

Finally, since ancient times, such as the Greco-Roman civilization, through Western medieval culture and without missing the oriental context, such as Japan and India, both drag performance and drag queens have interacted significantly with social issues. In all these scenarios, this work can be understood to be in line with the issue of gender-related movements like the feminist and LGBT movements (Amanajás, 2005). 


\section{LIFE HISTORY, COURSE, AND METHODOLOGICAL POSSIBILITIES}

Having briefly contextualized the place of drag artists and drag performativity, it is important to state that the methodological course for this research is found in the field of qualitative methodologies and emphasizes the research subject's singular and subjective constructions. This choice was made in view of the desired goal that clearly distances itself from the search for the objective apprehension of a universal reality. We seek to understand the meaning of work for the subject in question, starting from the singularity of the account of subject's life trajectory and affections as they intertwine with the historical and social contexts, which are elements we believe that constitute the subject's subjectivity. It is from this perspective that we take the methodological orientations of "life history."

From this perspective, the relations among researcher, method, and research subject constitute an important foundation for the development of the research. It would be unsuitable for an approach such as this to suppose that the researcher would take an active place with a strictly objective method against a solitary, passive research subject. What actually happens is a transparent relationship of mutual exchange based on trust and openness in which the interviewer comes to listen and the interviewee comes with a narrative of his history. The researcher must then seek to get rid of all his prejudices and previous and imaginary understandings to hear what is being carefully exposed while also recognizing the impossibility of getting rid of the interviewee's own subjectivity (Lopes, 2013).

"Life history" is a method as rich and ample as the experience of a life can be, including the affections, knowledge, and nuances of the subjectivity and imaginations of the subjects who construct and deconstruct meanings that made the plots of their individual and social histories. This method is concerned with approaching reality while preserving its complexity. Thus, it is necessary to "overcome the illusion of validity or the legitimacy of knowledge by its linear correspondence with feasible data, which would result in fragmentation and simplification of the social reality" (Lopes, 2013, p. 65).

Therefore, telling a personal story is a way to experience reflection. The truth of a fact is not what is in question but rather the "desire involving the story." It is because of all these processes (reflecting, assigning meaning, transforming, and learning) that this methodology also presents risks. Thus, 
this method can provide the subject who narrates his story with so-called "therapeutic" effects through simply sharing or re-signifying affections as well as exposing the narrator to the result of some subjective arrangement that protected him from suffering. One must take care not to invade the defenses of the interviewee. According to Lopes (2013), in data collection using life history as a methodological approach, the choice of what will be counted must come from the interviewee. This way, the interviewer should allow the interviewee to direct the interview by outlining his profile.

In this research, our procedures included some meetings with individuals who perform the artistic activity of drag queens as a source of income-that is, their main job. To choose the research subject, we prioritized the years of professional experience as a drag queen. The subject chosen for the interviews had been working as a drag artist for twenty years. We considered it relevant that the subject chose to work as a drag queen since the mid-1990s and had progressed in the career, supporting oneself financially through this activity.

Three interviews of approximately two hours each were used to collect the narrative of the life history of this subject. The initial request was, "Tell me your story." All interviews were conducted at the house of the interviewee and were recorded and transcribed. In addition, we made observations about some important facts of the subject's daily life, such as the purchase of materials and accessories for the shows; the design, production, and planning of performances during rehearsals; the process of setting up; and some performances of the artist in shows, parties, or nightclubs. After the interviews and observations, some impressions, feelings and affectionsdetails sometimes unexpected and of no apparent importance-were recorded in a field diary.

This diary was made to record the affections caused by the connection established between the researcher and the research subject, especially considering that such affections, those that the research subject (the interviewee) caused in the researcher (the interviewer), also compose the data of the research. All reports entered by the researcher in the field diary were presented in work supervision meetings with one of the researchers who had no contact with the interviewee and who, based on experience and psychoanalytic studies, could guide and conduct the collection process and analysis of the research data.

The rich reports produced by both the subject interviewed and the observations of the researcher support the reflections and clipping choices in the history of the subject that will be reported. Only after the report will we present the theoretical course that we intend to carry out on the case. 


\section{THE STORY OF STEVE ${ }^{4}$}

Narcissus and Eco embody the two versions pathetically separated: one, enamored look, victim of himself, object of his own spectacle; the other, reduced to the repetition of the word of another. (Assoun, 1999, p. 15)

Steve believes that his life trajectory has been marked by beauty from his birth. Of six brothers, he is the second youngest but still considers himself "practically" the youngest. He reports that he was always surrounded by compliments that especially praised his blue eyes and light hair. His first theatrical scene was around the age of five, playing the role of "little doctor" at his elementary school. He believes that he was selected precisely because of his physical characteristics, which distinguished him from his colleagues and siblings. This is the episode that represents for Steve the initial mark of his identification with the work of a performing artist:

There are people who become a doctor because his father was, because his grandfather was, or a lawyer. . . because it is the family tradition, ... and he ends up becoming a great lawyer, and I think it's my case, like this: I became an artist because they wanted me to be, and. . . and then, during my entire life, I identified myself with that (Interviewee 1).

Steve acknowledges his consent and even his desire to be recognized in this position:

Because nothing is by chance, is it?! And everything is a choice, and even if you are a child and under the responsibility of others, you are also making your choices ... aren't you?! When you throw a tantrum, ... hit your foot so that something does not happen, it is also a manifestation of your desire, and, if I did not do it, that means silence is consent (Interviewee 1).

Regarding his family, Steve narrates several points of conflict that marked him. He spent many years of his life without talking to his father, a

Steve is a fictitious name used to preserve the identity of the interviewee. It was attributed to try to represent the relation between the name of the subject and the name of the drag person that actually exists. 
man with a difficult personality, who did not have a good relationship with any of his children or with his wife, whom he even beat eventually. An alcoholic, he died at the age of seventy due to complications with alcoholism. Steve describes his father as a person who, despite his addiction, maintained an "elegant" and "arrogant" manner with which the subject identifies himself:

I had a father who was an alcoholic. . . . He did not cause many scandals; he was very simple, I mean in terms of alcoholism. But he was at the same time very elegant, so he did not make much noise in the street; he wouldn't drink in a bar, wouldn't fall on the street. At home, he took his vodka; it was not cachaça, ... and he shows already there a genetic characteristic of arrogance that I, too, have (Interviewee 1).

Another trait of the father that Steve admired is the elaborate way of reflecting on life and analyzing everyday facts:

This elaborate form of acting in life, just as I am philosophizing over various things-that's him, not my mother. My mother doesn't like it; my other siblings don't have it, nor have they inherited it, this ability to think, to analyze. . . . After I started to do therapy and such, we started to get in touch again, and there I can say that he died my friend, ... which relieves me (Interviewee 1).

Steve mentions an older sister who is also an alcoholic and cannot establish a good relationship with any of her siblings. One of the older brothers was diagnosed with schizophrenia at the age of thirteen and always demanded a lot of attention from his parents as well as several expensive treatments with the best doctors in the city. After going through long periods of crisis, his brother is now stable and able to socialize.

The other older brother died at the age of twenty-five in an accident of which Steve does not tell many details. As for his younger brother, just like his mother, Steve reports that they behave provocatively towards him. His younger brother was his friend during his childhood; however, he says that, after puberty, they became enemies because of daily problems. Currently, they do not have a relationship. However, Steve reports that he is very fond of his nephews, the children of his younger brother, and claims to have a good relationship with them.

Concerning his mother, he says that he initially considered her a hero; however, after a few years, he removed her from such a pedestal: 
but she's important to me, isn't she? Of course she's important to me. . . The thing is that I expected more; I did. . . . I expected more from her, understand? It's. . . like a person who comes before me, ... like a person who has a moment in life, ... moments in life that . . could have put her on a better level, you know? But this is no more. ... This has already been a crisis, a conflict; now, it's no more (Interviewee 1).

He also recognizes himself as passionate and "short-tempered person, which he partly attributes to the complexity of his family relationships:

So... in a way, I have this unbalanced load. . . I am very passionate; I lose my temper very easily. ... It's not just my brother, it's not just my father. ... Alcoholism is just the expression of madness from an emotional imbalance that the family has, ... and I do not think it's just part of my father. ... My mother was attracted to him because of this familiarity that is present in her too (Interviewee 1).

Steve acknowledges that he is exclusively homosexual and says he has never had sex with women. His childhood was also marked by an early sexual awakening. He reports that he still remembers his first experience in his childhood:

At age seven, in Rio de Janeiro, I had a sexual experience with a boy of the same age, seven years old, ... but with all the things that an adult does today (Interviewee 1).

By the age of thirteen, he already handled the fact that he was a homosexual well. At that age, he was aware, through a pornographic magazine, of the existence of other men who also had this sexual orientation:

And then, I saw in this little magazine that there were men who did this, that it was not just the salon fags, the crazy fags. . . . The feeling you get is that you're not alone (Interviewee 1).

His life trajectory went through an abrupt change during his adolescence: "And then, you come across another situation that is. . . [that] I have always been effeminate. ..." The question of social discrimination linked to his sexuality and gender then became a constant in his life. The beauty and perfection reflected in another's gaze gave way to the emptiness of being ignored; the scenery changed. He went from being an object of attention, 
care, affection, and appreciation from others to feeling abandoned and discriminated against. After he left his elementary school and started studying at a large "middle-class" high school in the city, he felt as if the other students did not want him to exist:

It's a very, very bad feeling. People don't know what it is like to be in that position.... I don't know how to describe it, but it's the majority, you know. . . . The majority-it's the majority. When I went to the schoolyard of a thousand students at recess-goodness, it was a horrible sensation, the sensation of being unprotected and threatened all the time. It's like. . . dying. It is a death wish. It's an assault. It's an assassination attempt. So, even if they are not physically assaulting you there, it's the position of ignoring you (Interviewee 1).

He does not consider himself a woman despite his feminine soul and appearance. It is a sense of exclusion that still accompanies him in adult life. He does not feel good in the presence of many people and does not accept being seen as a transvestite.

So, part of this public phobia, of being close to the public in my social life, is when I'm on the bus or in a congested area. . . . It brings me back to this persecution [referring to the bullying at school], which was, in fact, a persecution (Interviewee 1).

Little by little, Steve seems to have been able to find a place for his transgender position. However, regarding the drama of being seen as a transvestite, for Steve, there is only one automatic script:

It does not bother me if the person will call me he or she. What bothers me is the treatment, the adjective. Through the adjective, I'm going to have a discomfort or not. That's a recent thing, you know? Because to be recognized as a transvestite brings a whole load on your back; people will automatically think you're a whore. Automatically, because you're a whore, you're less of a person. Automatically, you're dirty. Automatically, you are carrying some disease. But that does not bother me (Interviewee 1).

As an outlet for the suffering he experienced daily under a gaze that he only recognizes as one of contempt and recrimination, the drag queen emerged. 


\section{1 "I am my own mother": The birth of Susie Stab ${ }^{5}$}

because, in a way, it is a gestation. . of an inner thing that is coming out for the role and from the role to flesh and bone. . flesh, bone, makeup, and hair.

His childhood stage experience resumed as he became a drag queen at the age of seventeen. At this same time, Steve dropped out of school and began to seek to establish his place in the world, mainly by working, and he found his place on stage through acting as a drag queen.

The character Steve plays is Susie Stab. The name is composed of opposites: Susie, the doll, and "stab," meaning to hurt, to pierce, to offend. Steve emphasizes that it is common for men who dress like women to be called dolls, and that is what that this choice relates to. He also says he learned of this name through a "busty, super drag" American singer with whom he identifies. While Susie has the more delicate sense associated with the image of a doll, Stab, according to Steve, symbolizes something penetrating. Besides that, he further says that this word is used in Portuguese in the masculine gender. He then finally contrasts the two: "As Susie is feminine, Stab is masculine to bring balance. . . . Susie is delicate; Stab is aggressive" (Interviewee 2).

Susie Stab is a woman who, according to Steve, has a "playful, fun, sensual, sexy, vulgar, or not" personality. As he says, she is a "naughty person." She was created in his drawings during childhood and adolescence, which were always related to a female image. That is why he claims to be his own mother; he compares the creation of the character to a gestation:

And, as I am my own mother in artistic terms, I then began to generate myself through drawings. And then, I had my experiences and my influences. . [ [crying] seeing the artists, the female expressions, the heroines, TV presenters, singers. ... My great influence is Madonna (Interviewee 2).

He says that it was in his childhood, watching transvestite presentations on television shows, that he saw the possibility of doing some artistic work with the practice of dressing as a woman. He found it interesting and noticed

Susie Stab is also a fictitious name, created from the characteristics of the actual name mentioned by the interviewee. 
an opportunity there. He recognizes as a facilitator the fact that he has a very feminine appearance: "People always asked whether I was a boy or a girl. ..." The process came naturally, since, when attending parties, he characterized himself, perfecting himself and receiving recognition, until he made a job of it and launched himself as Susie Stab twenty years ago.

Bringing up his drag queen performance to the family was a delicate process. He mentions the fable of The Grasshopper and the Ant: an underestimation of performative work in relation to conventional work. That was until his mother finally accepted his role of the Grasshopper:

I didn't tell my mother that I was a drag, but she always suspected that I took her clothes quietly. . . . I was in a play where I played a transsexual, a well-directed play, no comedy — on the contrary; it had funny moments, but it was a more reflective thing, and she watched it and loved it and even said I was the best in the play (Interviewee 2).

After some time, he invited his mother to watch a drag queen presentation. His mother's refusal to acknowledge and accept Steve's sexual orientation gradually gave way as she saw that her son had found a career as a drag queen and a place of social acceptance. Steve considered this to be an advantage since he could get dressed for his presentations at home.

The space, the place, the work environment is distinctive, marked, and full of very contemporary social and market values. It is not in the ghetto or in the gay underworld that Susie Stab finds the gaze that exalts her but, rather, at parties and in spaces where values, aesthetics, and sexual orientations blend and mix together. Susie Stab is a resident ${ }^{6}$ of one of the most important festivals of the city, and she has also started to work at highend parties:

I came from a more sophisticated culture, which is theater. Drag culture is more of a mass culture. But ever since I started, I started, instead of being in a gay nightclub, I was in a nightclub... that had gays, but it was focused on the alternatives, heterosexuals who also did not fit in this square format... This is already a differential of my beginning and also of my identity (Interviewee 2 ). also refers to an artistic residence-that is, the practice of living in the place where the work will be developed, in touch with the other contexts and members to produce an artistic work. 
It is work that carries in itself the contradiction of being both superfluous and necessary:

I also have the right to do my work that can be considered superfluous, but it is necessary. . . . People need this work; they need it for their party. . . and it is necessary. So, when we believe it, we know that we are useful. .. and, yes, it is necessary (Interviewee 2).

For Steve, being a drag queen is not restricted to a performance; it is an entire art, a beauty requirement, in setting up himself and his scenario, elements that make up his mask and his fantasy. His biggest concern is related to the satisfaction of his audience-that is, to fulfill the role to which he was assigned: to entertain, animate, and cheer. In this sense, the feeling of accomplishment in the work derives, above all, from the gaze of recognition of the public:

When I leave and go home, I get in the car and drive, and I think like this: my God, it was very good, it was great, I fulfilled what I had to do, the girls participated, I could make the jokes, everyone, yes. . . . It was fun, there was respect, the atmosphere was good, yes. . . . I did the show, everything was right. ... The beginning, middle, and end, people clapped, yes. ... I did my job on the stage. And people come, greet you, and say, "Wow, you're the best of the play" (Interviewee 2).

\section{WORK, IDENTIFICATION, AND THEIR MEANINGS}

The introduction of this article stated that an attentive look at the singularities and peculiarities of the place work occupies in the affections of subjects leads us to a renewal of questions addressing the study of the meanings of work. From a psychoanalytic point of view, how do the relations between identity and work take place? How does one include a dimension of meaning that carries a value (positive or negative)?

As Gomes Júnior (2018) shows, work and identification are always hand in hand. What we do with our lives - that is, our work with which we identify ourselves-is as important as our name. "I am so-and-so, I am a psychoanalyst," and so on. Our work always marks our identity. However, work should not always be taken as something positive a priori. The singularity of how the homology of work value operates and of our 
identification as subjects cannot be erased because of a standard identification with work. We must understand how the value of work, as the bearer of "knowledge," is tied to the dimension of "doing." This is a dimension that is only accessed when the relation of the subject with his or her office is heard. It involves both aspects of the social value attributed to work and its impact on satisfaction and how each "enjoys" doing it.

On one hand, to have a positive value, the work must carry an ideal with which the subject can orient and assert him or herself. On the other hand, every ideal has a symbolic dimension shared by language, built and disseminated in the culture. However, we should consider that our ideals also have an imaginary dimension, which is present in the identifications manifested in the forms of narcissism and in the singular form in which each enjoys life. Roughly, how these dimensions ${ }^{7}$ are articulated and tied, the instances of the symbolic and the imaginary, expresses the possibilities and impossibilities of the subject to deal with the real-that is, what cannot be named for him or her-and, therefore, is terrifying. Such ties compose our symptomatic way of living life, and our choices and actions at work are also possibilities and impossibilities of our knowing what to do with the symptom at work (Gomes Júnior, 2013).

Therefore, when we say that work has meaning, we really want to highlight the subjective value that it has for someone. This value, because it is subjective, leads us to new questions: value for whom? Does the value or meaning of the work always and only depend on each person? In other words, will it always be a value or an imponderable, personal, and individual meaning? The answer is no, because our subjectivity is, for us, always the conjunction of the expression of what is individual and social at the same time.

As Leguil (2012) shows, the meaning/value of work is supported by the value attributed to the know-how involved in an office. This value is like an ideal. This is a symbolic function developed in the culture, in the effort of civilization-that is, in a social dimension. It is this meaning/value that must serve as an imaginary support, nourishing the legitimate and singular narcissism on which each of our ways of life is based. Not only that, but this narcissistic satisfaction must also enclose the collective, allowing the reciprocity of interests that maintain the social bond. Thus, the appropriate know-how for an office must be sustained as an ideal; it must be based in 
what allows the subject to have a way to carry his or her unique way of life and to include this way in the collective dimension that the work involves (Gomes Júnior, 2013).

According to Leguil (2012), the fact that we can enjoy having specific knowledge gives us the possibility and authority to be recognized by others. This satisfies us narcissistically, guaranteeing the reciprocity of interests in the social bond where we earn our living. If this is knowledge worth recognition from others, it is exactly because it is knowledge that we are supposed to have: a supposed knowledge. All of us in our work desire to acquire knowledge that supposedly would respond to our ideals of power, of effective capacity, and especially of recognition by others. It is an authentic desire, which never ends, because there is always something to be known. If we are supposed to know, it mobilizes our desire and gives meaning to our work. It is a supposed knowledge but one that we believe we possess with the recognition of others (Leguil, 2012).

\section{BACK TO STEVE'S STORY}

It is undeniable that the subjective dynamics of Steve and his symptomatic way of living highlight the gaze of others as a field where his actions, his ways of dealing with life, are captured. The boy who attracted the gaze of everyone from birth to childhood; the chosen one to represent "the little doctor" in the school because of his beauty; scorned by teenage gaze; seen in the body of man and with soul and feminine manners. Susie Stab herself is born in response to Steve's demand for the gaze. The gaze of others seems to be the center of all conflict and the solution at the same time; it is where his subjectivity merges. It is from the gaze, taken as an object, that he obtains satisfaction, just as it is the gaze that brings all his anguish to the surface. His drama reminds us, as already described by Freud (1976), of the one lived by Narcissus, who, in love with his own image, becomes, in the words of Assoun (1999, p. 15), "a victim of himself, object of his own spectacle."

It is within this drama and with everything that composes it that Steve salvages elements for his identity construction. It is in it that he collects the signifiers which name and identify him: beautiful, artist (from his childhood), elegant, arrogant and elaborate (like his father), passionate and shorttempered (like his family dynamics), and, ultimately, homosexual (as in the magazines). It is exactly in this trait of his sexual identification that Steve seems to be in conflict all the time with the gaze of others, who see him as 
a transvestite-and, if he is seen as a transvestite, then he is seen as a whore, as less, as dirty, as sick.

Steve finds the outlet in a social production, which names and demarcates a place, not only of acceptance, but, above all, of valorization of the drag performance work: the drag queen. It is in the value assigned to this work that he sees a way out-an office where he finds a function for his most important identity traits, where such traits find a form of value and social recognition, where his know-how finds a value that comes from the gaze of others.

Knowing how to set-up (dress) is a trademark that distinguishes a drag queen. The creation of the costumes is one of the know-how features of this work. In the case of Steve, it is the clothes intended for work that ease something of his subjective conflict. This is because the clothes, the makeup, the costumes are artifacts capable of containing and revealing, at the same time, a whole symbolic and imaginary universe of this subject-just as, in some cases, the uniform as a work garment, as Farias (2010, p. 263) instructs, "can be considered more than an inert material designed to protect the workers. . . [as] it acquires an essentially dynamic social life, impregnated with memories, dreams and achievements, besides of being marked by persecutions, dismissals, fear and pain."

For the drag artist, the clothes both do and do not function as a uniform. A company uniform meets the need to match, through clothing, the workers and the hierarchy in the company (Farias, 2010). However, when wearing the same clothes as the boss, the worker is equal to the boss only at an imaginary level. On the other hand, it is a function so incorporated in the culture that it ends up sustaining a symbolic value. We know from psychoanalysis that one of the ways an imaginary construction can be linked to a symbolic function is through the production of a fantasy as a phantasmatic production. For this reason, we can say that it is a "fantasy" to think that a uniform can make employers and employees equal. Note that, in the fantasy, there is a dimension of unveiling and hiding a point of conflict. The uniform serves to hide at the same time as it reveals the conflict between the workers and the hierarchy in the company. The uniform, only at an imaginary level, equalizes workers and hierarchy, but, with this, it fulfills its symbolic function. This is a fantasy.

All these arguments lead us to recognize that the clothes do not equalize drag queens; they are not a uniform in this way. The clothes fulfill the function of fantasy. They address the conflict between masculine and feminine, exalting the feminine characteristics and hiding the masculine 
ones. In doing so as a caricature, however, the man is also present at the same time. Clothes for the drag queen do carry a sense of a uniform or tool; unlike the use of the uniform in most professions, there is no drag without clothes, makeup, and accessories. They are work tools, and knowing how to use them well will distinguish the professional.

In this sense, the performance unfolds in several steps: planning, elaboration of the costumes, purchase of accessories that compose it, setup, rehearsal, and presentation. The work is not restricted to the presentation. The whole process of assembling and building the character is part of the know-how that the craft requires. The value attributed to the use of clothing is central to the expertise in the work of a drag queen.

As shown above, part of the process of identifying with the work is the desire to acquire the knowledge that supposedly would respond to our ideals of power, of effective capacity, and, especially, of recognition by others. It is through identification with the work that Steve demonstrates his desire and knowledge developed for recognition as a good professional, knowledge that responds to his ideal of power:

In drag, I'm like a superhero; I'm, like, with the maximum power I can have. And it's still me. Because I was the one who produced this power. It was no one else. Because they say: "Ah, you have to believe in yourself. .." as if that was not me. . . as if the professional was not personal (Interviewee 1).

The social value attributed to the drag queen since the late 1980s is crucial to Steve's professional choice. This is a critical and unquestionable dimension of the meaning of this work, a profession being glamorized and included in spaces that previously rejected practices of drag performance. It was a positive action on the meaning of this work, valuing it and categorizing it as an artistic expression with space and value in pop culture.

\section{FINAL CONSIDERATIONS}

The unconventional form in which this article was structured, beginning with the exposition of the subject's life story, refers us not only to the assumptions of the life history methodology but also to the demands of more clinical studies that allow access to more subjective aspects of the relation with work. In this article, all argumentation centers on the narrative 
produced and presented here. It is from this narrative that we were able to find, mainly in the psychoanalytical literature, theoretical foundations for an analysis of the elements that make up the meaning of drag queen work for Steve: the look and the clothes as traces that sustain a fantasy that has found a place in society.

Unlike the functionalist mainstream, where the meaning of the work can be transcribed through models from a sample, for psychoanalysis, singularity is the pillar that sustains its epistemological and ontological conception. This goes with the use of the life history methodology to try to understand, at least in part, how the subject builds meaning for his or her work.

If, on one hand, psychoanalysis invite us to think that it is impossible to transcribe/translate meaning-said to be unique-when we consider unconscious dimensions, on the other hand, it is necessary to understand that the theoretical/methodological discussion adopted here allows us to look into the histories of the subjects, allowing us to unveil part of this singularity crossed by a social one. Considering the dialectic between the micro and the macro, the singular and the collective, the work is only right when it makes sense both for the individual and the society.

Considering that the objective of this article was to understand some traits of the identification processes that marked the life of a subject and its possible relations with the meaning of a drag queen's work, we understand that it is with the purpose and in the socially constructed place for the expression and production of the artistic work of the drag queen that the subject in question found an expression outlet of identity traits that are more part of subjectivity.

The popularization of a drag queen's work opened up a whole social space that allowed this subject to find value and recognition in an office that preserves important elements of his identity, his fantasy, and his way of enjoying life, all at the same time. The dress-that is, the costume of the drag queen-is both his work tool and his uniform. As a uniform, it fulfills less the function of uniformization and much more a psychic, phantasmatic function of hiding and unveiling a point of conflict.

By bringing concepts and possibilities of readings from psychoanalysis to the field of administration and studies on organization, work, and management, we intend to contribute to broadening the understanding of the phenomena at stake when we treat the "meanings of work." We believe we have shown that not everything that makes up the meaning of work is conscious, and there is always in the meaning of work a dimension of the unconscious desire that each of us has, which requires listening to the subjects individually. 


\section{IDENTIFICAÇÃO E SENTIDO NO TRABALHO DE DRAG QUEEN}

\section{RESUMO}

Objetivo: este artigo tem como objetivo compreender alguns traços dos processos identificatórios que marcaram a vida de um sujeito e suas possíveis relações com o sentido do trabalho de drag queen.

Originalidade/valor: este estudo destaca-se pelo uso de um arcabouço teórico psicanalítico para analisar a história de vida de um sujeito que atua profissionalmente como drag queen, visando lançar luzes sobre os sentidos do trabalho a partir de aspectos singulares do próprio trabalhador, reconhecendo-se que as pesquisas sobre essa temática no campo da administração usualmente partem de um paradigma funcionalista.

Design/metodologia/abordagem: os dados analisados compõem a história de vida de uma drag queen da cidade de Belo Horizonte, Minas Gerais, sendo que a escolha pela metodologia de "História de Vida", como estratégia de coleta e análise dos dados, possibilitou lançar luz sobre o modo como o sujeito vivencia e articula sua história à escolha de um trabalho que o possibilita uma expressão do seu desejo.

Resultados: é possível destacar alguns pontos que conjugam seus traços identitários com trabalho de transformista: o olhar e as vestimentas como elementos que sustentam uma fantasia que encontrou um lugar social. Um dos elementos que dá sentido ao trabalho é o enlace de algum traço identitário, sempre singular, com a dimensão social do trabalho e os afetos que sustentam uma forma de reconhecimento social.

\section{PALAVRAS-CHAVE}

Drag Queen. Trabalho. História de Vida. Olhar.

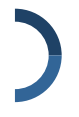

\section{REFERENCES}

Álvarez R. N., \& Pérez P. C. (2009). Identidad de género en transformistas: Un estudio cualitativo-exploratorio. Límite, 4(20). 
Amanajas, I. (2015). Drag queen: Um percurso histórico pela arte dos atores transformistas. Revista Belas Artes, 6(16), 1-23.

Arnaud, G. (2012). The contribution of psychoanalysis contribution to organization studies and management: An overview. Organization Studies, $33(9)$.

Arnaud, G., \& Vanheule, S. (2007). The division of the subject and the organization: A Lacanian approach to subjectivity at work. Journal of Organizational Change Management, 20(3), 359-369.

Assoun, P. (1999). O olhar e a voz: Lições psicanalíticas sobre o olhar e a voz. Rio de Janeiro, RJ: Companhia de Freud.

Baker, R. (1994). Drag: A history of female impersonation in the performing arts. New York, NY: New York University Press.

Butler, J., \& Trouble, G. (1990). Feminism and the subversion of identity. New York, NY: Routledge.

Caproni Neto, H. L. (2016). Fazendo e desfazendo gênero: Xs drag queens de Belo Horizonte (Unpublished master's thesis). Universidade Federal de Minas Gerais, Belo Horizonte, MG.

Chidiac, M. T. V., \& Oltramari, L. C. (2004). Ser e estar drag queen: Um estudo sobre a configuração da identidade queer. Estudos de Psicologia, 9(3), 471-478.

Farias, R. D. C. P. (2010). Transubstanciação simbólica do uniforme de trabalho em signo de prestígio. Anais do Museu Paulista: História e Cultura Material, 18(2), 263-284.

Fotaki, M., Long, S., \& Schwartz, H. S. (2012). What can psychoanalysis offer organization studies today? Taking stock of current developments and thinking about future directions. Organization Studies, 33(9), 11051120.

Freud, S. (1976). Sobre o narcisismo: Uma introdução. In: S. Freud, Edição standard brasileira das obras completas de Sigmund Freud (Vol. 14, pp. 89-119). Rio de Janeiro, RJ: Imago.

Gomes Júnior, A. B. (2013). O uso de si e o saber fazer com o sintoma no trabalho (Unpublished cotutelle doctoral dissertation). Aix Marseille Université, Marseille, FR; and Universidade Federal de Minas Gerais, Belo Horizonte, MG.

Gomes Júnior, A. B. (2018) Resistência e trabalho: Reflexões a partir da ergologia e da psicanálise. Revista Brasileira de Estudos Organizacionais, 5(1), 80-96. 
Gomes Júnior, A. B., Lopes, F. T., \& Guimaraes, L. V. M. (2015). Diálogos sobre o trabalho humano: Perspectivas clínicas de pesquisa e intervenção. Farol—Revista de Estudos Organizacionais e Sociedade, 2(1), 709-728.

Jayme, J. G. (2001). Travestis, transformistas, drag-queens, transexuais: Personagens e máscaras no cotidiano de Belo Horizonte e Lisboa (Unpublished doctoral dissertation). Universidade Estadual de Campinas, Campinas, SP.

Jesus, J. G. (2012). Orientações sobre identidade de gênero: Conceitos e termos. Retrieved from http://www.sertao.ufg.br/n/42117-orientacoessobre-identidade-de-genero-conceitos-e-termos

Leguil, F. (2012). Postface. Souffrances au travail: Rencontres avec des Psychanalystes. Paris, FR: Association Souffrances Au Travail.

Lopes, F. T. (2013). Entre o prazer e o sofrimento: Histórias de vida, drogas e trabalho (Unpublished doctoral dissertation). Universidade Federal de Minas Gerais, Belo Horizonte, MG.

Moraes, R. R. C. (2015). Rupal's drag race e seu fandom: Um nicho em expansão. Cambassu—Estudos de Comunicação, 15(16), 94-104.

Pelúcio, L. (2009). Abjeção e desejo: Uma etnografia travesti sobre o modelo Preventivo de AIDS. São Paulo, SP: Annablume.

Safatle, V. (2007). Lacan. São Paulo, SP: Publifolha.

Silva, R. S. (2015). Drag queens, montagens e reinvenções: Tecendo outras existências (Unpublished master thesis). Universidade Federal de Juiz de Fora, Juiz de Fora, MG.

\section{AUTHOR NOTES}

Thaís Z. G. de Oliveira, Departamento de Ciências Sociais e Aplicadas, Centro Federal de Educação Tecnológica de Minas Gerais (CEFET-MG); Ludmila de V. M. Guimarães, Centro de Pesquisas e Pós-Graduação em Administração, Universidade Federal de Minas Gerais (UFMG) and Université du Quebec à Montreal; Mariana de L. Caeiro, Programa de Pós-Graduação em Administração, Pontifícia Universidade Católica de Minas Gerais (PUC-MG); and Admardo Bonifácio Gomes Júnior, Faculdade de Educação and Collège Doctoral Aix-Marseille Université, Universidade Federal de Minas Gerais and Aix-Marseille Université.

Thaís Z. G. de Oliveira is now Master's Dregree student at Centro de Pesquisa e Pós-Graduação em Administração (CEPEAD) at Universidade Federal de Minas Gerais (UFMG); Ludmila de V. M. Guimarães is now Professor of Administration at Centro Federal de Educação Tecnológica de Minas Gerais (CEFET-MG); Mariana de L. Caeiro is now Ph.D student at Programa de Pós-Graduação em Administração at Pontifícia Universidade Católica de Minas Gerais (PUC-MG), \& Admardo Bonifácio G. Júnior is now Adjunct Professor of Administration at Centro Federal de Educação Tecnológica de Minas Gerais (CEFET-MG). 
Thaís Z. G. de Oliveira, Ludmila de V. M. Guimarães, Mariana de L. Caeiro, Admardo B. Gomes Júnior

Correspondence concerning this article should be addressed to Ludmila de V. M. Guimarães, Rua Rodrigues Caldas, 458, Santo Agostinho, Belo Horizonte, Minas Gerais, Brazil, CEP 30190-120.

E-mail: ludmilavmg@gmail.com

\section{EDITORIAL BOARD}

Editor-in-chief

Silvio Popadiuk

Associated Editor

Andrea Rodrigues

Technical Support

Vitória Batista Santos Silva

\section{EDITORIAL PRODUCTION}

Publishing Coordination

Irina Migliari

Language Editor

Daniel Leão

Editorial Trainee

Maria Luiza Vanz

Layout Designer

Emap

Copy Editor

Irina Migliari
Graphic Designer

Libro 